Viso - Cadernos de estética aplicada Revista eletrônica de estética

ISSN 1981-4062

$N^{0} 5$, jul-dez/2008

http://www.revistaviso.com.br/
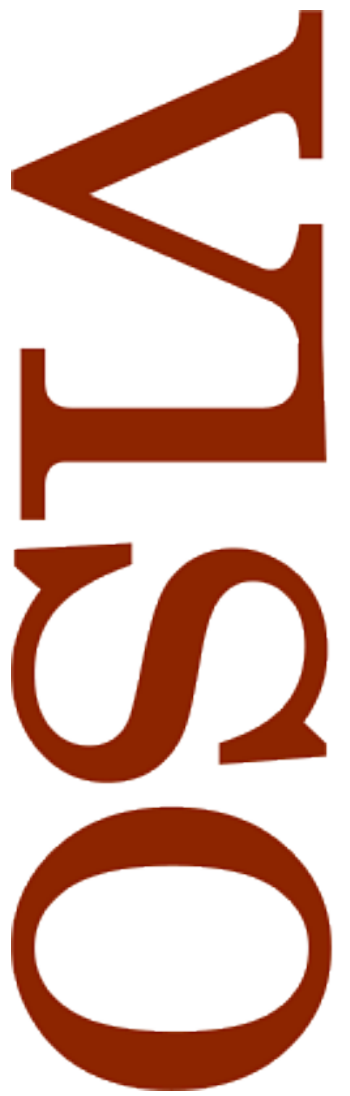

\title{
Espiritualidade mundana: O trabalho como construção do real Renata Camargo Sá
}




\section{RESUMO}

\section{Espiritualidade mundana: $O$ trabalho como construção do real}

O artigo analisa aspectos da obra de Johannes Vermeer e Richard Serra buscando esclarecer o modo pelo qual ambos baseiam sua poética na idéia de trabalho como construção do real. Tal perspectiva antecipa a substituição da noção de trabalho como punição pela de construção do mundo civilizado para a Holanda seiscentista, e aponta o artista Richard Serra como aquele que melhor representa o ponto de culminância desse processo histórico.

Palavras-chave: pintura - trabalho - Vermeer - Richard Serra

\section{ABSTRACT}

Mundane spirituality: Work as the construction of the real

The article analyses some aspects of the creative biographies of Johannes Vermeer and Richard Serra with the intent of disclosing their links with the modern ethics of work. Such perspective views the beginning of the notion of labor as a constructive activity in the Netherlands during the seicento, and suggests that Richard Serra is the artist who better represents the vertices of this historical process in contemporary art.

Keywords: painting - work - Vermeer - Richard Serra 


\section{SÁ, R. C. "Espiritualidade mundana: O trabalho como construção do real". In: Viso: Cadernos de estética aplicada, v. II, n. 5 (jul-dez/2008), pp. 66-79.}

DOI: $10.22409 / 1981-4062 / v 5 i / 66$

Aprovado: 03.12.2008. Publicado: 29.12.2008.

(C) 2008 Renata Camargo Sá. Esse documento é distribuído nos termos da licença Creative Commons Atribuição-NãoComercial 4.0 Internacional (CC-BY-NC), que permite, exceto para fins comerciais, copiar e redistribuir o material em qualquer formato ou meio, bem como remixá-lo, transformá-lo ou criar a partir dele, desde que seja dado o devido crédito e indicada a licença sob a qual ele foi originalmente publicado.

Licença: http://creativecommons.org/licenses/by-nc/4.0/deed.pt_BR

Accepted: 03.12.2008. Published: 29.12.2008.

(C) 2008 Renata Camargo Sá. This document is distributed under the terms of a Creative Commons Attribution-NonCommercial 4.0 International license (CC-BY-NC) which allows, except for commercial purposes, to copy and redistribute the material in any medium or format and to remix, transform, and build upon the material, provided the original work is properly cited and states its license.

License: http://creativecommons.org/licenses/by-nc/4.0/ 
Esse artigo relaciona a obra de Richard Serra com a de Johannes Vermeer, no que tange especificamente às situações de imanência das quais ambas dependem e promovem enquanto condições indispensáveis para sua existência. A aproximação entre os dois artistas busca esclarecer o processo que culminou no colapso das grandes hierarquias que regiam as tradições artísticas ocidentais. Tal processo vem se desenrolando desde a Holanda seiscentista, culminando no modernismo tardio de Richard Serra. Os primeiros passos em direção a uma concepção de arte como fazer mundano ocorreram na Holanda devido à ênfase no trabalho, compreendido não mais como purgação de pecados, mas como construção do mundo civilizado. A obra de Richard Serra incorpora certas questões essenciais inauguradas pela pintura de gênero holandesa de modo a representar o vértice do que se convencionou denominar "utopia moderna do plano".

O significado literal da palavra inglesa prop (suporte) nos induz a pensar os Prop Pieces, série de trabalhos de Richard Serra da década de 1980, no contexto da célebre máxima minimalista: "o que você vê é o que você vê". Afinal, a principal função dessas esculturas é suportarem-se a si mesmas. Reféns de uma situação de equilíbrio aparentemente precário, as chapas de aço apóiam-se umas às outras para evitar sucumbir à gravidade e colapsar, autodestruindo-se. Se o que vemos fosse só o que vemos, a única razão para

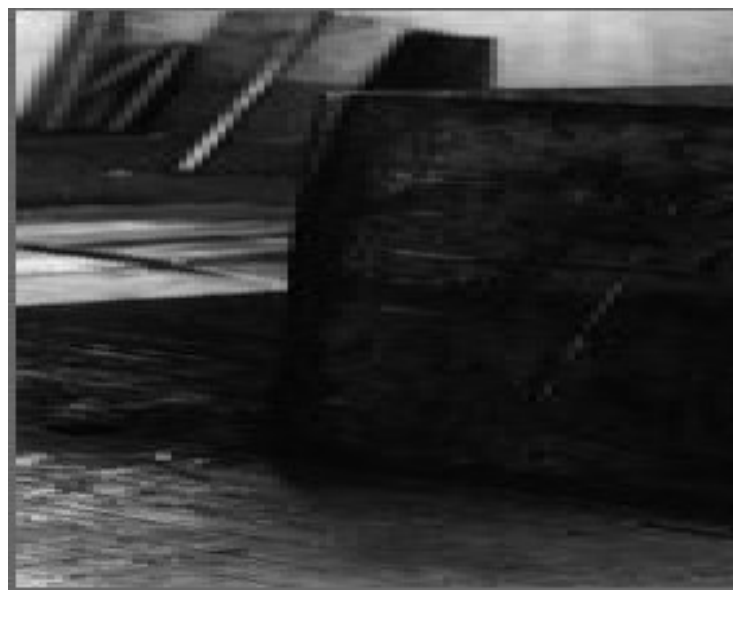

Richard Serra - One Ton Prop, 1969 existirem seria sua condição de suporte. O nome corresponderia à coisa, literalmente: a obra nada mais seria do que uma tentativa de impedir sua queda. $O$ fato de estarem nessa situação - na condição provisória de suporte - já diz muito de sua ontologia: são seres em trânsito. O caráter situacional implica uma segunda condição, a de imanência. E, finalmente, encontram-se acomodadas a partir do esforço que exercem umas sobre as outras.

Apesar de idênticas, as chapas não possuem todos os requisitos do que se convencionou denominar elemento. Simplesmente, porque o esforço necessário para se manterem lhes impõe uma interdependência. A rigor, portanto, não se trataria de uma forma aberta, no sentido tradicional do minimalismo. Afinal, próprio desse tipo de formalização é justamente o fato de os elementos poderem prescindir uns dos outros. Os Prop Pieces impossibilitam tanto o acréscimo quanto a retirada de uma das chapas. Como numa composição clássica, tais procedimentos desequilibrariam o conjunto. O que não significa, necessariamente, que essas esculturas sejam compositivas, baseadas nos princípios morfológicos da combinação de partes, teleologicamente orientadas para produzir um todo harmônico. Porém, se seu tipo de formalização em princípio não condiz com a lógica das partes, tampouco se adequa de todo ao conceito de forma aberta, na qual elementos regimentam a lógica formal. ${ }^{1}$ 
O conceito de elemento foi aplicado de maneira mais metódica à obra dos minimalistas americanos na década de 60. Richard Serra iniciou sua carreira nesse métier, por isso convém considerar com atenção o papel do minimalismo e do conceito de série, que the é conexo, em sua prática artística. Nos Prop Pieces, a idéia de série, contudo, mais do que apontar para as experiências minimalistas com elementos, relaciona-se à prática comum na história da arte das variações sobre o mesmo tema. Neste caso, o tema é uma série de suportes em aço.

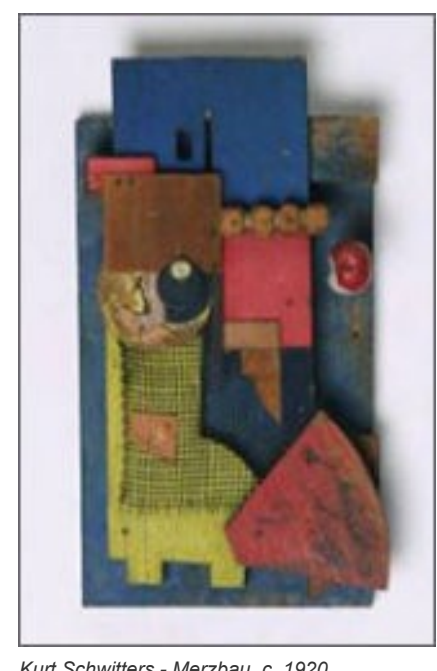

Kurt Schwitters - Merzbau, c. 1920

A idéia de série - fundamental para a noção de forma aberta surge na arte moderna avant la lettre com a aplicação de objetos industrializados, ou simulacros, às colagens, por Picasso e Braque. Na década de 20, os Merzbauten de Schwitters mostraram que a idéia de série se apoiava num tipo de fazer em que se acrescentam elementos ao invés de combiná-los; destróise assim a própria noção de composição relacional, ao atribuir-se aos elementos valor ontológico igual no processo de fabricação da obra. Alguns anos antes, em 1912, com os ready-mades, o pensamento serial já assumia perfil conceitual bem definido. Os ready-mades, por um lado, realmente encarnam o caráter anônimo da modernidade, tão próprio à idéia de série, ou de "composição" seqüencial; por outro, revivem certo romantismo (também moderno) ao reafirmarem a posição de decisão do artista sobre o que é e o que não é uma obra de arte. Nesse sentido atualizam, paradoxalmente, a proposição humanista de transformar a arte num saber consagrado a poucos. Afinal, o gesto duchampiano pressupõe que somente o artista é capaz de atribuir a um objeto banal o estatuto de arte. Andy Warhol radicaliza a ambigüidade inaugurada por Duchamp quando transforma a si mesmo numa espécie de pop-star do anonimato.

O anonimato moderno, observou Rosalind $\mathrm{Krauss}^{2}$, prevê que as operações sejam forjadas pela matéria, não pela inspiração. Nesse intricado procedimento revela-se o estigma do objeto moderno: sua autonomia no mundo. Por meio desse procedimento, o paradigma de uma estética de cunho humanista - o fazer divino e a obra acabada - foi substituído por outro, em que o processo (a fabricação humana propriamente dita) ganhou preponderância sobre a obra realizada. Portanto, a questão da série é indissociável dos processos de feitura e fruição, estruturais na concepção de um objeto autônomo. Essa questão corrobora também a desconstrução desse mesmo objeto, agora apenas um seguimento dentro de uma série de incontáveis processos.

O serialismo, no âmbito social e cultural, está estreitamente vinculado à produção capitalista, e remonta inclusive à sobriedade do vestuário dos puritanos, como demonstrara Max Weber. Com o objetivo de evitar a ostentação, eles estabeleceram as primeiras regras para a uniformidade da vida. Weber vê nessa conduta a preferência dos puritanos pelo modelo utilitário, que requisita uma atitude racionalista diante da vida. 
Atitude impassível diante dos desígnios carnais, representados tradicionalmente pelas tendências artísticas. ${ }^{3}$ Segundo Weber, a iconoclastia protestante foi uma aliada na luta para enfraquecer a importância da carne, presença fortíssima na arte ocidental, latina e católica, sobretudo a partir do Renascimento. Simmel, de onde saíram muitas dessas teorias de Weber, observa a uniformidade do terno, unânime representante de uma expressão não apenas de sobriedade, mas também de igualdade.

O serialismo na arte, portanto, não se divorcia nem do caráter anticarnal mencionado por Weber, nem tampouco da atitude econômica, conseqüentemente racionalizante, a ele atribuído. Enquanto modelo anti-antropomórfico, o serialismo serve exemplarmente ao propósito de superar o privilégio da inspiração, o que é apenas uma das conseqüências da falência de uma entidade supra-humana. Afinal, só uma entidade supra-humana (Deus) é capaz de presentear o artista com o "dom" da inspiração. Inspiração é, portanto, um conceito essencialmente metafísico. As colagens de Picasso, onde identificamos a gênese da lógica serial no modernismo, são casos exemplares do rompimento com o antropomorfismo. Uma estética que deseja desvencilhar-se do modelo humanista deve lidar, antes de mais nada, com outro conceito de natureza e de cultura. Nele, o fazer humano precisa ter um papel muito mais significativo. Contudo, tal fazer demanda "um método sistemático de conduta racional, com a finalidade de superar o status naturae". ${ }^{4}$

O aparente tênue equilíbrio dos Prop Pieces pode facilmente ser comparado à instabilidade da existência ou à dinâmica da vida, aproximando-se assim das questões mais recorrentes sobre as quais se debruçou grande parte das experiências artísticas desde meados do século XX. A influência exercida pelas filosofias européias de cunho existencialista - em particular a fenomenologia de Maurice Merleau-Ponty - no grupo de jovens minimalistas americanos da década de 60 avaliza tal linha interpretativa. Hoje, entretanto, tendemos a pensar que uma análise pautada pelo conceito modernista de visibilidade pura, a partir do "o que você vê é o que você vê" dos minimalistas, não satisfaz, por ser difícil crer que o que nos é dado à visão seja absolutamente tudo o que há.

A experiência cotidiana do que nos é apresentado como real, na forma de imagem, cada vez nos leva a duvidar mais do que vemos. Além disso, a atual realidade virtual da cibernética tampouco nos permite afirmar sartreanamente que só o que aparece é o que de fato há. Não se está a supor nova metafísica, mas, ao analisar-se a questão da gravidade na obra de Serra, há de se ponderar a multiplicidade de significados que se produzem no contato com ela, muitas vezes oriundos dos remanescentes mnemônicos surgidos no curso de uma experiência estética, sempre permeada pelo momento histórico.

Por isso, não nos interessa a repetitiva teoria sobre os Prop Pieces evidenciarem o peso da gravidade, para que o espectador-transeunte perceba materialmente a força gravitacional a que está submetido. Interessa-nos, sim, indagar, por exemplo: para quê se perceber preso à Terra? Ou: o que se sente frente à iminente queda? Em outras 
palavras: se uma experiência é sempre contaminada pela cultura e pela história, não sendo jamais "pura", quais contágios culturais podemos perceber ao experimentar esteticamente a obra do artista Richard Serra?

Perguntas como essas nos levaram a buscar sua formação junto às origens religiosas da cultura americana, e não apenas nas memórias mais recentes do pós-minimalismo e da filosofia européia de tendência existencialista. Pensamos que seus remanescentes históricos podem revelar-se mais próximos da pintura de gênero holandesa do século XVII do que se poderia a princípio supor. Aquelas pinturas são o produto dos primeiros artistas comissionados pela emergente burguesia protestante européia, que iria, em parte, neste mesmo século, refugiar-se na América fugindo de perseguições religiosas. Quando pensamos num Vermeer, com seus quase-pecados, naquela pureza sutil prestes a ser maculada, a iminente queda dos Prop Pieces parece encontrar seus antecedentes. O equilíbrio precário da virtude, representado nas telas do pintor holandês, parece revisitado pela arte moderna. É como se, mesmo metamorfoseando-se em aço-corten, latências daquela velha virtude, temerosa de si mesma, permanecessem naquelas chapas de aço, tensionadas pelas conseqüências drásticas da queda iminente.

Sabemos que a analogia tende a parecer demasiadamente ousada, em se tratando da obra de um artista tão avesso à idéia de alma. Porém, fique claro que não estamos a supor qualquer religiosidade na obra de Richard Serra, nem buscando significados intrínsecos em chapas de aço. Estamos, isto sim, recusando deliberadamente um tipo de leitura, quase canonizada sobre sua obra, baseada em pressupostos estritamente modernistas, para, com um olhar menos fossilizado, observá-la ora em seu atual ambiente cultural, ora naquele que o formou direta ou indiretamente. Sua obra nos parece mais consonante com a história das mentalidades na América - pautada, sobretudo, pela estética, pela ética e pela moral protestante - do que com o existencialismo francês, de onde partem as investigações estritamente formalistas sobre sua poética. Seguindo os conselhos de Tocqueville, que conhece bem o assunto América, "foi a religião que deu origem às sociedades anglo-americanas - nunca se deve esquecer este fato". ${ }^{5}$

Tanto Johannes Vermeer quanto Richard Serra empenharam-se numa reflexão visual sobre a existência. Ambos encontraram no trabalho o meio mais legítimo de realizá-la. O trabalho, notese, compreendido não como purgação de pecados, mas como fazer construtivo numa sociedade desierarquizada. Foi na Holanda onde

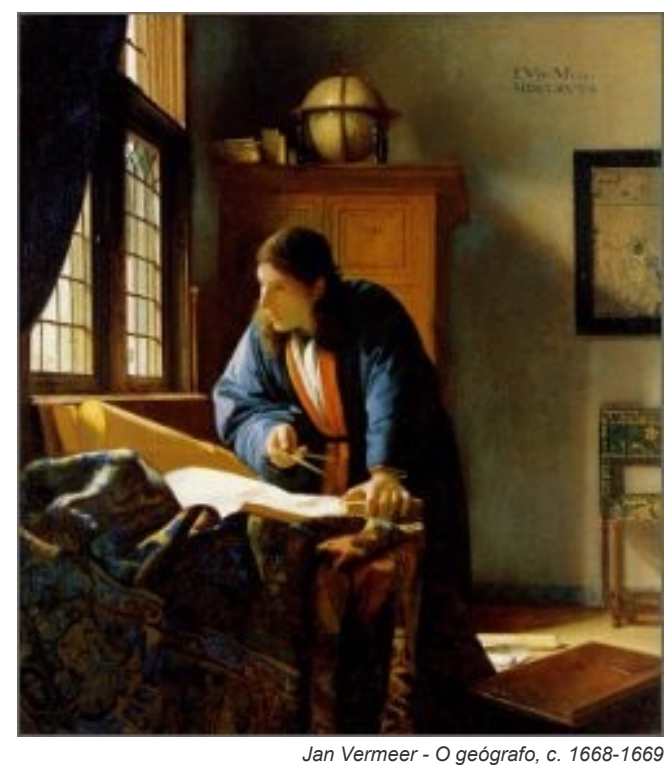

Jan Vermeer - O geógrafo, c. 1668-1669 primeiro se desenvolveu uma forma democrática de governo, associada a uma economia 
capitalista. Conjunção que irá alcançar na América do Norte seu estado mais avançado. Por isso, a concentração do Geógrafo não difere, no plano moral, da concentração da Empregada servindo leite (c.1660) ou da Rendeira. Por isso, o fazer artístico depende tanto do metalúrgico quanto do projetista de CATIA ou AutoCad. Em ambos, a virtude se revela no fazer laico de construção do real.

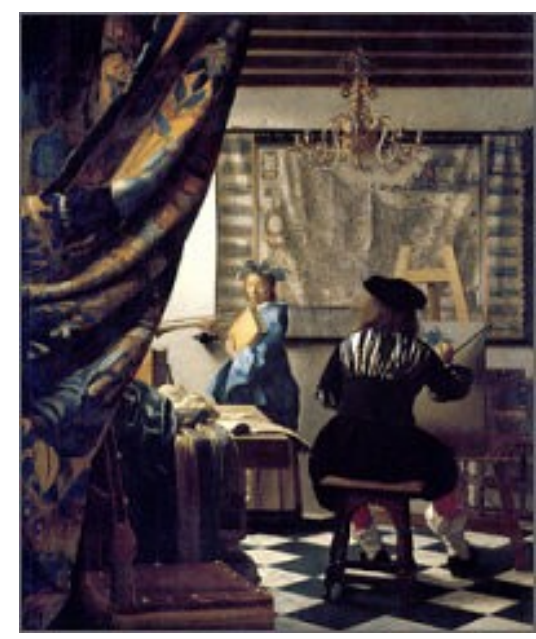

Jan Vermeer - O pintor em seu estúdio, c. 1665

A obra de Serra e as pinturas de Vermeer são muito autocentradas, o que thes confere uma densidade peculiar. Sua espessura existencial provém de uma intensa concentração de forças, proporcionando o equilíbrio que as mantêm em pé. Em Serra, diferenças milimétricas, na intensidade do esforço empregado por cada uma das chapas, poriam tudo a perder. Pôr tudo a perder é inutilizar o próprio ser-obra, destruí-lo por completo. Nos quadros de Vermeer, são sobretudo as figuras que promovem tal densidade, quando praticamente ignoram o espectador, compenetradas que estão em seus afazeres cotidianos. Colocam-se mesmo de costas para ele (O pintor em seu estúdio). Elas não "posam" para ninguém - nem poderiam - pois isto seria distrair-se de tais afazeres, que justamente Ihes conferem existência, sejam eles intelectuais ou braçais. Como nas esculturas e desenhos de Richard Serra, somente a concentração e o esforço do trabalho garantem espessura vital. Sabemos disso porque percebemos, de modo sensorial, o esforço aplicado pelas enormes Hugh Smiths ${ }^{6}$ sobre as placas de aço-corten para que atinjam a espessura e curvatura desejadas para as Ellypses, por exemplo. Também sabemos que o esforço é fundamental, porque ele nos é demandado para fruí-las. O esforço da ação, do movimento em torno e por entre as peças.

Quase todas as pinturas de Vermeer representam uma ação produtiva. Uma acepção da moral bem diferente de tantas obras do gênero de pintores do calibre de um Jan Steen, por exemplo. Notório por suas pinturas de cunho moralizante, Steen partia, entretanto, de uma inversão temática: representava o ilícito, o moralmente reprovável. Suas personagens favoritas, médicos e professores, sempre negligentes, pecam pela preguiça, o desleixo e o vício. O desprezo e a ironia com que esses profissionais eram tratados nas peças de Molière e, no século anterior, por Montaigne, revela seu descrédito perante a população.

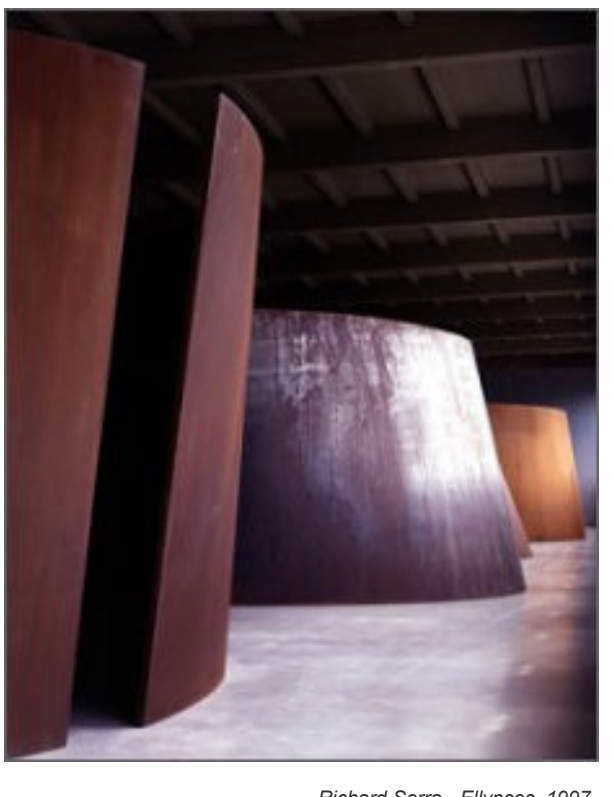

Richard Serra - Ellypses, 1997 
Em Vermeer, o ambiente é outro. Mesmo o comércio, a rigor condenável pela conotação de usura a ele associado, pode conter alguma grandeza, e ser eticamente tolerado. A comerciante de pérolas, por exemplo, é uma representante de sua vocação. ${ }^{7}$ Nessa tela, o truque maneirista de inversão mostra o Juízo Final em segundo plano, admoestando sobre os limites frágeis entre a virtude do comércio e o vício da agiotagem. Pinturas como as de Vermeer revelam as origens de um modo de conceber a existência onde o trabalho, mais do que parte integrante, é o que funda a realidade e o ser, é "a própria finalidade da vida". ${ }^{8}$

O trabalho como vocação se distingue fundamentalmente da idéia de trabalho como destino. Enquanto o destino não permite ao homem qualquer ingerência sobre o mundo, a vocação, ao contrário, faz parte do universo da intencionalidade - depende da vontade humana segui-la ou não, incorrer ou não no pecado de descumprir um mandamento divino. Por ser um mandamento, explica Weber, ninguém deve fugir de sua vocação, nem mesmo os ricos. Tampouco a produtividade monástica, limitada à contemplação, à oração e ao canto, via-se eximida do trabalho. O trabalho como instrumento ascético, preventivo contra as tentações e capaz de dar forma à existência, ganha, através desse viés da vocação, um prestígio inédito na história.

O caráter austero da arte de Richard Serra, a economia dos meios plásticos, o alerta constante à fragilidade do equilíbrio, e a sobriedade de suas esculturas e desenhos, sua atitude, enfim, em nenhum sentido frívola ou escandalosa, teriam, em nosso entender, na tradição religiosa americana, proveniente do calvinismo e do luteranismo europeus, seus antecedentes éticos, morais e estéticos. O peso da existência, quer dizer, o embate contínuo e inescapável com o real, comporia o fazer terreno a revelar-se em atitude moral, indissociável de um puritanismo latente. A relação, portanto, entre o perigo da queda em pecado, nas pinturas holandesas, e a iminência da queda física dos Prop Pieces, devido à gravidade, revela-se no fato de ambas apoiarem-se num esforço físico e moral para manterem-se firmes.

Uma das obras seminais de Richard Serra, um filme de 1967, onde uma mão permanece, durante os três minutos da película, tentando agarrar pedaços de chumbo que caem repetidamente, sintetiza muito do que estava por vir. Nele, a constante iminência da queda e o esforço repetitivo e seqüencial para impedi-la constituem o núcleo da obra, assim como seu centro de tensão. Ao buscarmos em sua poética afinidades com o protestantismo, a idéia de queda ganha contornos muito próprios. O mundo no qual viemos a cair é o mundo sensível, e suas peças habitam claramente no mundo decaído. Sua dependência do sensório comprova tal afirmação. O resultado da queda é a inescapável luta contra a inação, que no mundo humano constitui o trabalho. 


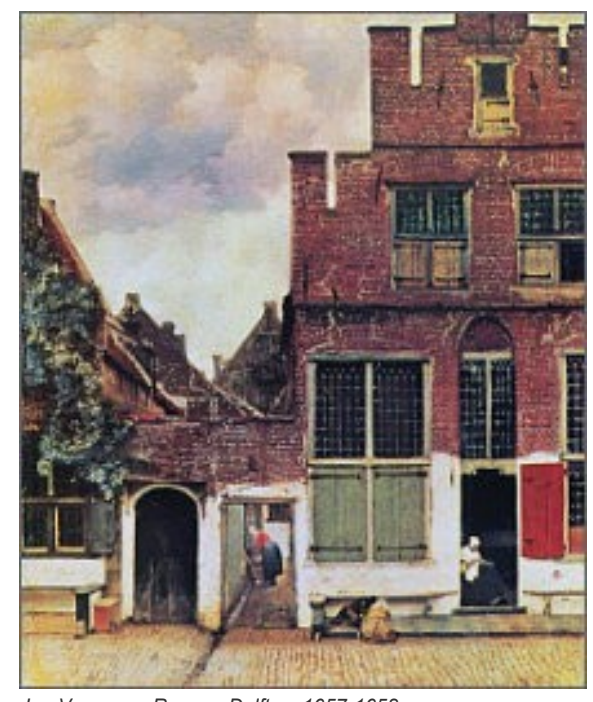

Jan Vermeer - Rua em Delft, c. 1657-1658
A tela clássica de Vermeer, intitulada Rua em Delft, apresenta quatro personagens concentradas de tal forma em suas tarefas cotidianas que parecem estar cumprindo um chamado espiritual (as crianças inclusive). Convém ressaltar que a tradução da palavra vocação em inglês é calling. Claro que tal chamado, chamado à ação, observe-se bem, retorna e reflete sobre o observador da cena, este que é ao mesmo tempo artista e espectador. Por ser o trabalho um fazer moral, Vermeer imprime à cena uma sofisticação plástica, que a eleva à altura de uma pintura religiosa. Comparemos a tela de Vermeer a outra $(A$ apresentação), de seu contemporâneo Ter Borch. Repare-se a preocupação deste em pintar a textura

dos objetos. A vulgaridade do episódio ${ }^{9}$ é representada pela valorização das coisas: o brilho dos metais e a falaciosa suntuosidade dos tecidos.

A carne, representada pelo colo da jovem cortejada, é tratada de modo quase obsceno, como um objeto; e a luz, desprovida de simbolismos, emana justo dali para atingir propositalmente o rosto do galanteador. A história narrada por Ter Borch é moralmente condenável, assim demonstram seus recursos pictóricos: a iluminação, a disposição das personagens na composição, a manipulação da matéria.

A comparação com Ter Borch ajuda a esclarecer o procedimento inverso de Vermeer, diante da realidade e do fazer artístico. A Rua em Delft é uma pintura austera e seu centro recai sobre a ação

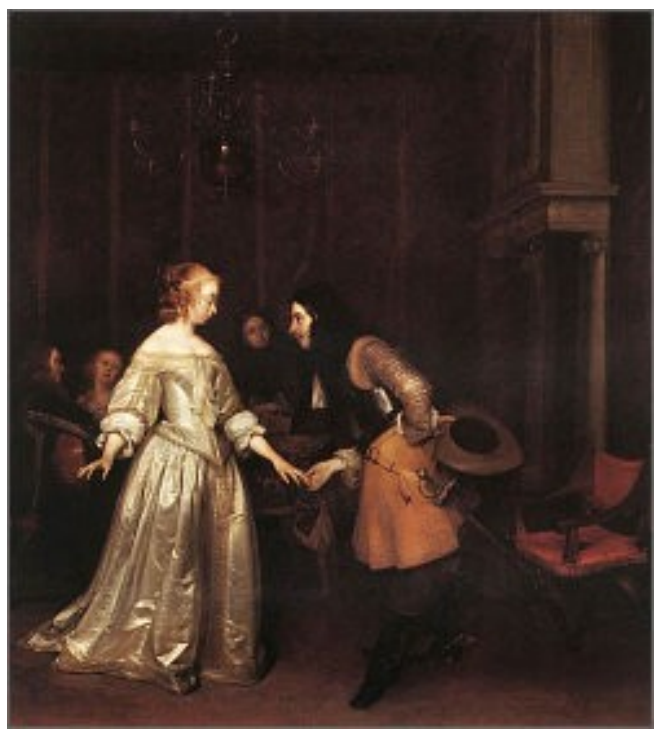

Gerard ter Rorch - A anresentacão c. 16ศ das personagens. $\mathrm{O}$ rigor de sua composição, reduzida a horizontais e verticais, e a uma paleta extremamente econômica, revelam seu característico decoro, mas revelam também uma compreensão da realidade como equilíbrio de massas. $O$ que tais elementos comunicam a respeito de uma ética do fazer é o que de fato nos ocupa. $E$, nesse sentido, sua afinidade com Mondrian ultrapassa e muito a questão meramente compositiva, tantas vezes comentada. Aliás, a afinidade não é só com Mondrian, mas também com Rembrandt e Van Gogh. ${ }^{10}$ A massa pictórica das telas dos três artistas demonstra uma valorização do ofício da pintura sem precedentes na história da arte, a 
verter-se para o religioso. É verdade que esses artistas dividem com os venezianos a tradição de construir com a cor, mas a espessura do emplastro, como marca de um fazer braçal, só pode resultar daquela compreensão do trabalho como atividade moral, tão comum na cultura de países protestantes.

Diferentemente de Ter Borch, a pintura de Vermeer eleva a realidade a um estatuto superior, sem contudo idealizá-la. $\mathrm{O}$ ato de pintar, que inclui observar e descrever o real, constitui uma função social, desvencilhada do idealismo fortemente impregnado na prática artística dos países latinos. A elevação da realidade provém da ocupação produtiva do artista e da dedicação das personagens a atividades tão comuns. De modo semelhante, a rusticidade do muro caiado, as marcas do uso e do tempo nas portas e janelas e os toscos tijolos de barro revelam o pendor ético de uma arte que expõe a estrutura do real. Qualquer tentativa de abrilhantá-lo, como em Ter Borch, poderia vulgarizá-lo, rebaixando-o. A luminosidade, observe-se, vem da verdade comum da caiação, não da carne luxuriosa. O tema em si não é casual, evidentemente, ele oferece a oportunidade para um novo exercício de pintura. A rua - lugar típico do homem moderno - é espaço mundano por excelência. Através dessa abordagem ética, contudo, Vermeer consegue transfigurar em gênero superior - em pintura religiosa e histórica - o retrato do cotidiano urbano.

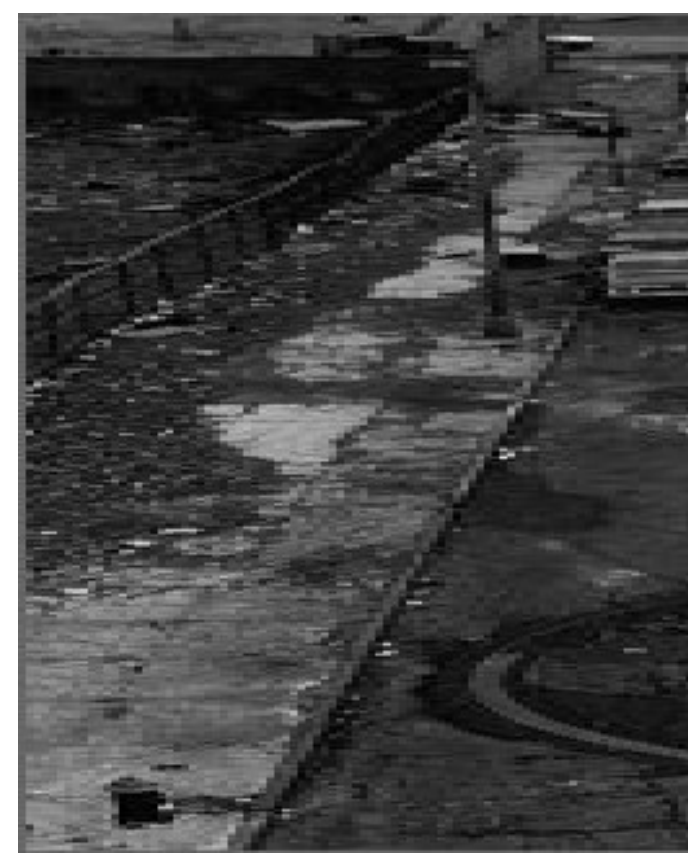

RichardSerra
Trata-se, portanto, ousaríamos dizer, de uma forma de "sacralizar o mundano", ao the atribuir valor de verdade, estabelecendo, ademais, um intercâmbio entre as esferas do sagrado e do profano. Tal momento representa, parece-nos, justamente a gênese do projeto moderno de desierarquizar o sistema de arte. Não existe então parentesco entre a rejeição de Vermeer do decorativo e a adesão da obra de Richard Serra a sua verdade estrutural (o aço sem pintura ou acabamento)? Ou entre uma pintura como Rua em Delft e o círculo de Serra, colocado no rés-do-chão de um lugar junk, numa via do Bronx? Em outras palavras: não estaria naquelas pinturas holandesas a origem do materialismo moderno, conseqüência lógica do que veio a transformar-se na própria falência do humanismo clássico?

A "vulgarização" da arte na modernidade, portanto, parece inserir-se num processo histórico bem definido. Nele, a apropriação de temáticas banais pela pintura de gênero, tratadas de modo nada idealizado, no limiar da Holanda moderna, culmina numa arte 
impassível diante da idéia de transcendência. Pinturas de paisagens, retratos de pessoas comuns, naturezas-mortas são temas que sempre estiveram numa situação limítrofe. Nelas, pintor e espectador são a mesma pessoa. Arrisco-me inclusive a afirmar que já vem dessa conjunção o abandono da condição passiva de quem espera, característica do espectador tradicional, em prol de uma postura mais ativa diante da própria arte e da realidade.

É evidente que tais condições irão redefinir a perspectiva renascentista de um ponto de vista. Ao que podemos avaliar pelas pinturas de Vermeer e de seus contemporâneos holandeses, o olhar seiscentista antecipa a dinâmica do olhar encarnado da arte moderna, depois de Cézanne. As pinturas daquele período distinguem-se por sua visada meio fotográfica, pois retratam quase sempre flagrantes do cotidiano, cenas vistas de soslaio. Como se observou anteriormente, as personagens não estão ali a posar. Foram como que flagradas por um observador despercebido, anunciando inclusive o voyeurismo que faz parte da complexa relação entre público e privado na modernidade.

Fundamental é o fato de que o observador dessas pinturas divide o mesmo espaço com as figuras representadas, qualificando de voyeur também o espectador. Trata-se de um observador que, em trânsito, numa via pública, testemunha determinado episódio da lida diária: o trato com a casa ou com as crianças; ou, por um corredor, ao acaso, vê de esguelha uma toalete matinal; através de uma cortina levantada, desvela o segredo de uma carta recebida. O pintor registra como numa fotografia, mais do que narra, fatos furtivos que se colocam ao seu olhar, num realismo inédito na história da pintura. Numa representação clássica, o pintor não poderia ser um observador, porque não teria como dividir o mesmo espaço com seus personagens. O repertório não permitia tal "intimidade", pois repousava sobre pintura histórica, religiosa e mitológica. Apenas a paisagem e o retrato davam alguma margem para que o pintor se inserisse na cena, como vemos acontecer de forma nada ortodoxa em As meninas. Com a pintura holandesa, o "realismo" vem do fato de todos os participantes, pintor, espectador e personagens, estarem envolvidos na mesma trama espacial.

No domínio das artes plásticas, o privilégio da visualidade sobre os demais sentidos precisou ser combatido. A tendência para se rever a supremacia da visualidade nos domínios da estética há muito vem afastando a preponderância do olhar da prática artística. Na verdade, se quisermos precisar o início da falência da visualidade na arte ocidental, podemos sem hesitar datá-la no Impressionismo, ou seja, quando os artistas começam a estudar o modo como a percepção visual se dá. Por tratar-se a pintura impressionista de uma profunda reflexão visual sobre a fisiologia do olhar, é ali também que a anatomia do sujeito encarnado começa a revelar-se. O projeto que visa a desierarquizar o universo artístico quer eliminar a supremacia do olhar, completando assim o ciclo modernista: o olhar encarnado de Cézanne passa pela grade de Mondrian e pela teia de Pollock e parece culminar no espectador-transeunte de Richard Serra. 
Uma arte voltada para descrever a natureza (como a pintura holandesa e o Impressionismo) diferencia-se fundamentalmente de outra voltada para representá-la. A representação da natureza faz parte de um sistema no qual, como constructo divino, a natureza serve de paradigma para a construção humana. A descrição da natureza, por sua vez, tem como parâmetro o constructo humano - a arte -, o ato de pintar propriamente. Decerto, a arte seiscentista holandesa não é concreta, no sentido modernista engendrado pelo termo realismo, porém ela tem mais afinidades com o caráter objectual deste do que com o naturalismo, com todo seu idealismo e imitatio. Quando afirmamos que tal arte não é simbólica, é porque aquilo que apresenta para seus espectadores é lugar-comum.

As pinturas de Vermeer talvez sejam tão canônicas para a história da arte porque, embora ainda se submetam a certos princípios da representação naturalista, elas rejeitam o idealismo que Ihe é inerente. Em sua obra a natureza começa a perder seu estatuto de paradigma para o fazer humano. Se, como pensamos, é por ali também que sutilmente vai se inaugurando o projeto moderno de desierarquização da arte, é porque sua pintura parece depositar na fabricação humana a responsabilidade de construir o mundo. Não apenas por lidar com temas do cotidiano, mas por tratá-los de forma nobre, enaltecendo o dia-a-dia e o fazer do homem.

Trata-se de um longo processo, a culminar na brilhante e definitiva constatação de Malone de que "a natureza acabou". Processo que caracteriza a própria modernidade em sua tentativa gradual de destruir a racionalidade abstrata, representada por uma entidade transcendental. O "novo" humanismo nietzschiano, sem um Deus para dar garantias, tornou tal processo ainda mais evidente. Quando a natureza, fruto da própria razão transcendental, "acaba", só sobra o mundo da cultura, ou seja, caos e desordem. Não é isso, por exemplo, que as serigrafias de Andy Warhol constatam? Que o modelo não é mais a natureza, mas os objetos da cultura? Objetos sem dono, mas que pertencem a todos?

O fenômeno, portanto, considerado essencialmente modernista, em que a arte extrapola seus limites institucionalizados, objetivando atingir o mundo inteiro, tem seus primórdios muito antes das vanguardas do início do século XX. O processo de desierarquização da arte é longo e envolve bem mais do que fatores meramente artísticos. Trata-se de uma lenta transformação do modo mesmo de conceber a existência e da necessidade de criar uma espacialidade apropriada para acolher essa nova forma de existência.

\section{* Renata Camargo Sá é professora de Teoria e Método em Cultura da UFF.}

1 Quando elementos regimentam a lógica formal, eliminam-se as hierarquias clássicas da composição parte-extra-parte. Em se tratando de elementos, não há de fato composição, mas uma organização de elementos cujo objetivo é a função e não a "beleza". Denomina-se esta uma forma 
"aberta" pois sempre é possível alterá-la, acrescentando ou retirando um ou mais elementos (já que é a utilidade o que irá determinar sua configuração).

${ }^{2}$ Krauss, R. Catálogo da exposição Sculptures - Richard Serra. New York: Museum of Modern Art, 1986, p 16.

${ }^{3}$ Weber, M. A ética protestante e o espírito do capitalismo. Tradução de M. Irene de Q.F. Szmrecsányi e Tamás J. M. Szmrecsányi. São Paulo: Pioneira, 2001, p 121.

${ }^{4}$ Ibidem p. 83.

${ }^{5}$ Tocqueville, A. A democracia na América - Livro I. Tradução de Eduardo Brandão. São Paulo: Martins Fontes, 2001, p. 06.

${ }^{6}$ Hugh Smiths são as máquinas que literalmente espremem o aço para moldá-lo. São usadas na indústria siderúrgica para a fabricação de navios.

${ }^{7}$ Weber, M. Op. cit., p. 49.

${ }^{8}$ Ibidem, p. 113.

${ }^{9}$ As leituras mais confiáveis sobre essa tela afirmam que ela representa a negociação do matrimônio da moça com o galanteador.

${ }^{10}$ A eliminação do decorativismo pela Bauhaus deve ser pensada também em relação a essa "política econômica" da arte holandesa em destaque na pintura de Vermeer. 